\title{
Kemampuan argumentasi siswa: Perbandingan model pembelajaran inkuiri terbimbing dan inkuiri terbimbing dipadu dialog Socrates
}

\author{
Dewi Ekaputri Pitorini *, Suciati Suciati, Joko Ariyanto \\ Program Studi Pendidikan Biologi, Fakultas Keguruan dan Ilmu Pendidikan, Universitas Sebelas Maret. \\ Jalan Ir. Sutami 36 A Kentingan, Surakarta, Indonesia. \\ * Corresponding Author. Email: dewiekaputripitorini@gmail.com
}

Received: 23 October 2019; Revised: 2 January 2020; Accepted: 13 January 2020

\begin{abstract}
Abstrak: Penelitian bertujuan untuk mengetahui ada atau tidaknya perbedaan kemampuan argumentasi ilmiah tertulis siswa melalui model pembelajaran Inkuiri Terbimbing dengan Inkuiri Terbimbing dipadu Dialog Socrates. Penelitian ini menggunakan metode quasi experimental research dengan desain penelitian post-test only with nonequivalent group design. Populasi dalam penelitian ini adalah seluruh siswa kelas XI IPA SMA Negeri A Karanganyar Tahun Pelajaran 2018/2019. Teknik pengambilan sampel yang digunakan adalah cluster random sampling. Sampel dalam penelitian ini adalah kelas XI IPA 1 sebagai kelas eksperimen 1 dengan model pembelajaran Inkuiri Terbimbing dan kelas XI IPA 2 sebagai kelas eksperimen 2 dengan model pembelajaran Inkuiri Terbimbing dipadu Dialog Socrates. Teknik pengumpulan data menggunakan teknik tes dan teknik non tes. Uji hipotesis yang digunakan adalah uji t. Hasil penelitian menunjukkan bahwa nilai rata-rata argumentasi ilmiah tertulis kelas eksperimen 2 lebih tinggi yaitu 74,44 dibandingkan dengan kelas eksperimen 1 yaitu 65,99. Hasil uji t menunjukkan bahwa $t_{\text {hitung }}>t_{\text {tabel }}(4,675>1,99444)$, artinya terdapat perbedaan kemampuan argumentasi ilmiah tertulis siswa yang signifikan antara kelas eksperimen 1 dan kelas eksperimen 2. Simpulan penelitian ini adalah bahwa ada perbedaan kemampuan argumentasi ilmiah tertulis siswa melalui model pembelajaran Inkuiri Terbimbing dengan Inkuiri Terbimbing dipadu Dialog Socrates.
\end{abstract}

Kata Kunci: kemampuan argumentasi ilmiah tertulis, inkuiri terbimbing, dialog socrates

\section{Students' argumentation skills: A comparison between the guided-inquiry learning model and the Socrates dialogue-integrated guided-inquiry learning model}

\begin{abstract}
The research aimed to determine whether there was a difference in students' written scientific argumentation skills through Guided Inquiry learning model and Guided Inquiry learning model integrated with Socratic Dialogue. The research was quasi experimental research. The research design used was posttest only with nonequivalent group design. The population in this research were all students of class XI IPA of SMA Negeri A Karanganyar academic year 2018/2019. The sampling technique used in this research was cluster random sampling. The sample in this study was class XI IPA 1 as the experimental class 1 with the Guided Inquiry learning model and class XI IPA 2 as the experimental class 2 with the Guided Inquiry learning model combined with Socrates Dialogue. The data collection technique used was test technique and non-test technique. The hypothesis test used was $t$ test. The results of the research showed that the average scientific written argument for the experimental class 2 was higher at 74.44 compared to the experimental class 1 at 65.99. The $t$-test results show that $t_{\text {count }}>t_{\text {table }}(4,675>1,99444)$, meaning that there were significant differences in students' written scientific argumentation skills between the experimental class 1 and the experimental class 2. The conclusion of this study was that there was a difference in students' written scientific argumentation skills through the Guided Inquiry learning model with Guided Inquiry learning model integrated with Socrates Dialogue.
\end{abstract}

Keywords: written scientific argumentation skills, guided inquiry, socratic dialogue

How to Cite: Pitorini, D., Suciati, S., \& Ariyanto, J. (2020). Kemampuan argumentasi siswa: Perbandingan model pembelajaran inkuiri terbimbing dan inkuiri terbimbing dipadu dialog Socrates. Jurnal Inovasi Pendidikan IPA, 6(1), 26-38. doi:https://doi.org/10.21831/jipi.v6i1.27761 


\section{PENDAHULUAN}

Pembelajaran yang baik adalah pembelajaran yang mampu mengembangkan keterampilan abad 21 (Kulsum \& Nugraha, 2014). Trilling dan Fadel (2009) menyatakan bahwa pembelajaran abad 21 menuntut siswa untuk memiliki keterampilan 4C, yaitu critical thinking and problem solving, creativity and inovation, collaboration, dan communication. Argumentasi ilmiah merupakan salah satu keterampilan komunikasi yang memainkan peran penting dalam pembelajaran sains (Kurniasari \& Setyarsih, 2017). Argumentasi merupakan proses memperkuat suatu klaim melalui analisis berpikir kritis berdasarkan dukungan bukti-bukti dan alasan yang logis (Pangestika, Ramli, \& Nurmiyati, 2017). Argumentasi ilmiah terdiri dari claim, evidence dan reasoning (McNeill, et al., 2006).

Argumentasi ilmiah berperan penting dalam pembelajaran sains karena dapat melatih literasi sains, mengembangkan kemampuan berpikir kritis, meningkatkan pemahaman konseptual siswa, dan merupakan pusat dari penalaran ilmiah (Deane \& Song, 2014; Duschl \& Osborne, 2002; Osborne, 2010; Pangestika, Ramli, Nurmiyati, et al., 2017). Argumentasi ilmiah dapat membantu siswa dalam membuat keputusan dan memungkinkan siswa bekerja dengan cara para ilmuwan (Faize, Husain, \& Nisar, 2018). Argumentasi ilmiah tertulis bermanfaat untuk mengembangkan pengetahuan ilmiah dan kemampuan menulis siswa (Meghan, et al., 2015).

Argumentasi ilmiah berperan penting dalam proses penyelidikan pada pembelajaran Biologi. Biologi sebagai bagian dari sains memiliki perbedaan dengan mata pelajaran lain. Aslan (2014) menyatakan bahwa perbedaan tersebut terlihat dari cara konsep sains dikonstruksi. Proses konstruksi konsep sains tersebut memengaruhi pembelajaran sains. Bass et al. (2008) menyatakan bahwa pembelajaran sains seharusnya memfasilitasi siswa untuk terlibat dalam kegiatan penyelidikan. Penyelidikan merupakan aktivitas ilmiah yang digunakan oleh para ilmuwan untuk menjelaskan fenomena alam dan argumentasi ilmiah ikut berperan dalam kegiatan penyelidikan tersebut (Wenning, 2005).

Hasil PISA yang diselenggarakan oleh OECD pada 2015 menunjukkan bahwa Indonesia masih di bawah rata-rata dalam hal literasi sains (Organisation for Economic Co-Operation and Development, 2016). Literasi sains diukur berdasarkan kemampuan siswa untuk memberikan argumentasi ilmiah dan kontra-argumen. Hasil menunjukkan bahwa siswa masih sulit untuk menemukan bukti yang menjadi dasar argumen, hal tersebut dikarenakan siswa belum dapat mengubah data yang diperoleh menjadi bukti nyata untuk mendukung klaim (Nurinda et al., 2018b).

Hasil penelitian sebelumnya juga menunjukkan bahwa kemampuan argumentasi ilmiah tertulis siswa masih rendah. Wibawa et al. (2017) menyatakan bahwa berdasarkan analisis hasil observasi kelas $\mathrm{X}$ di salah satu SMA di Boyolali, kemampuan argumentasi ilmiah tertulis siswa kelas X SMA masih tergolong rendah yaitu sebesar $36,55 \%$, yang terdiri dari claim sebesar 50,88\%; evidence sebesar 35,09\%; dan reasoning sebesar 23,68\%. Hasil penelitian Amielia et al. (2017) pada kelas XI di salah satu SMA di Surakarta menunjukkan bahwa kemampuan argumentasi siswa masih tergolong rendah, perolehan presentase rata-rata keterampilan argumentasi pada aspek claim sebesar 44,08\%; evidence sebesar 26,88\%; reasoning sebesar 20,43\%; dan rebuttal sebesar 0\%. Rata-rata keterampilan argumentasi siswa $22,84 \%$.

Fakta di lapangan juga menunjukkan bahwa kemampuan argumentasi ilmiah siswa masih rendah. Hasil observasi pra-penelitian menunjukkan bahwa hanya sedikit siswa yang aktif menjawab pertanyaan guru selama proses pembelajaran. Siswa menanggapi pertanyaan guru dengan jawaban singkat. Jawaban yang diberikan oleh siswa bukan merupakan pernyataan argumentatif.

Rendahnya kemampuan argumentasi ilmiah siswa disebabkan oleh pembelajaran yang masih didominasi oleh guru (teacher centered). Pembelajaran belum memfasilitasi siswa untuk melakukan argumentasi ilmiah. Pertanyaan yang diberikan oleh guru juga belum mampu mendorong siswa untuk menyampaikan argumentasi mereka, karena guru lebih banyak mengajukan pertanyaan yang sifatnya hafalan. Hal tersebut didukung dengan temuan hasil observasi lapangan yang dilakukan oleh (Wibawa et al., 2017) di salah satu SMA di Boyolali yang menunjukkan bahwa pembelajaran masih berpusat pada guru sehingga belum mampu memberdayakan kemampuan argumentasi ilmiah tertulis siswa. Hasil prapenelitian yang dilakukan oleh Aisyah dan Wasis (2015) di salah satu SMA di Pacet menunjukkan bahwa pembelajaran di kelas masih menggunakan metode ceramah, dimana siswa hanya menerima informasi dari guru kemudian mencatatnya.

Argumentasi ilmiah dapat dikembangkan melalui model pembelajaran yang mengarahkan siswa untuk melakukan kegiatan penyelidikan layaknya ilmuwan. Model pembelajaran inkuiri terbimbing 


\section{Jurnal Inovasi Pendidikan IPA, 6 (1), 2020 - 28}

Dewi Ekaputri Pitorini, Suciati Suciati, Joko Ariyanto

merupakan salah satu model pembelajaran yang sesuai untuk melatihkan kemampuan argumentasi ilmiah. Model pembelajaran Inkuiri Terbimbing mengajak siswa untuk mengembangkan pengetahuan mereka sendiri melalui kegiatan penyelidikan dengan bimbingan dari guru (Kuhlthau et al., 2007). Tahapan model Inkuiri terbimbing terdiri dari orientation, conceptualization, investigation, conclusion, dan discussion (Pedaste et al., 2015).

Nurinda et al. (2018b) menyatakan bahwa pembelajaran berbasis Inkuiri melatih siswa membangun penjelasan yang mendukung argumen melalui kegiatan penyelidikan fenomena atau masalah. National Research Council (1996) menyatakan bahwa kegiatan inkuiri melatih siswa untuk melakukan penyelidikan ilmiah guna menemukan serta meninjau kembali penjelasan saintifik dengan menggunakan logika serta bukti yang telah diperoleh untuk kemudian mengkomunikasikan serta mempertahankan argumentasi ilmiahnya. Aisyah dan Wasis (2015) menjelaskan bahwa pembelajaran Inkuiri dapat melatihkan kemapuan argumentasi ilmiah yang meliputi claim, evidence, dan reasoning. Kegiatan merumuskan hipotesis melatih siswa mengajukan claim atau gagasan berdasarkan pengetahuan awal siswa. Penyelidikan yang dilakukan melatih siswa untuk mengumpulkan bukti (evidence) guna mendukung gagasan yang diajukan. Kegiatan analisis data pada proses penyelidikan melatih siswa untuk membangun pembenaran (reasoning) guna menguatkan claim yang diajukan.

Kelemahan model pembelajaran Inkuiri yaitu siswa kesulitan merubah cara belajar yang awalnya hanya menerima informasi dari guru menjadi siswa aktif membangun konsep mereka sendiri (Simbolon, 2015). Guru dapat mengatasi kelemahan tersebut dengan cara menyediakan bimbingan kepada siswa melalui kegiatan tanya jawab (Kawalkar \& Vijapurkar, 2013). Pertanyaan guru juga dapat melatih argumentasi ilmiah siswa. Dialog Socrates merupakan salah satu teknik bertanya yang dapat digunakan untuk membimbing siswa sekaligus melatihkan kemampuan argumentasi ilmiah siswa.

Dialog Socrates merupakan metode yang berasal dari kebiasaan percakapan yang dilakukan oleh filsuf Yunani Kuno, Socrates untuk membimbing siswa-siswanya memahami suatu konsep (Pangestika, Ramli, Nurmiyati, et al., 2017; Vyskočilová \& Praško, 2012). Pertanyaan digunakan dalam Dialog Socrates untuk membantu memperluas pandangan mengenai masalah tertentu dan kemudian mengubah pandangan berdasarkan hasil dialog bersama. Pertanyaan yang diajukan dalam Dialog Socrates bersifat terbuka dan memiliki lebih dari satu jawaban benar. Koellner-Clark et al. (2002) menyatakan bahwa Dialog Socrates melatih kemampuan argumentasi siswa melalui kegiatan penalaran dan komunikasi.

Dialog Socrates merupakan teknik pembelajaran di mana guru mengajukan pertanyaan untuk membantu siswa meninjau kembali pengetahuan mereka dan memeriksa validitas pernyataan mereka. Dialog Socrates melatih siswa untuk berpikir mengenai alasan (reasoning) dan tanggapan (response) mereka (Yengin \& Karahoca, 2012). Dialog Socrates terdiri dari dua tahapan. Tahap pertama, guru menggunakan dialog untuk menunjukkan kepada siswa bahwa pengetahuan awal yang digunakan untuk menjawab pertanyaan belum memadai. Pertanyaan yang diajukan pertama kali adalah pertanyaan yang bersifat umum, seringkali dalam bentuk pertanyaan "Apa . . . ?" dan kemudian siswa menjawab (misalnya, memberikan definisi). Siswa dilatih untuk mengajukan claim berdasarkan pengetahuan awal pada tahap pertama. Tahap kedua menuntut siswa untuk menganalisis masalah lebih detail dan mendalam untuk mencapai solusi atau pernyataan. Guru mengarahkan siswa untuk membentuk konsep baru melalui pemikiran dan analisis lebih lanjut. Siswa dilatih untuk mengajukan evidence dan reasoning pada tahap kedua (Yengin \& Karahoca, 2012; Whiteley, 2006).

Penelitian sebelumnya menunjukkan bahwa model pembelajaran Inkuiri Terbimbing dapat melatih kemampuan argumentasi ilmiah siswa. Penelitian yang dilakukan oleh Aisyah dan Wasis (2015) menunjukkan bahwa model pembelajaran Inkuiri mampu meningkatkan kemampuan argumentasi ilmiah siswa. Penelitian yang dilakukan oleh Wilson, et al., (2010) menemukan bahwa model pembelajaran Inkuiri lebih baik dibandingkan model konvensional untuk melatih kemampuan argumentasi ilmiah. Acar dan Patton (2015) menemukan bahwa penerapan model pembelajaran Inkuiri dapat meningkatkan kemampuan argumentasi siswa. Penelitian yang dilakukan oleh Thoron dan Myers (2012) menunjukkan bahwa siswa yang diajar melalui instruksi berbasis Inkuiri memiliki kemampuan argumentasi yang lebih baik. Penelitian sebelumnya juga menunjukkan bahwa Dialog Socrates dapat melatih kemampuan argumentasi ilmiah siswa. Gumilar dan Budiman (2018) menyatakan bahwa Dialog Socrates dapat melatih kemampuan argumentasi siswa. Pangestika, Ramli, dan Nurmiyati (2017) menemukan bahwa penerapan Dialog Socrates memberikan perubahan positif terhadap kemampuan argumentasi siswa. 


\section{Jurnal Inovasi Pendidikan IPA, 6 (1), 2020 - 29}

Dewi Ekaputri Pitorini, Suciati Suciati, Joko Ariyanto

Penggunaan Dialog Socrates dalam pembelajaran Inkuiri terbimbing dapat menciptakan suasana yang kondusif untuk argumentasi siswa. Inkuiri merupakan pembelajaran berbasis pertanyaan. Pertanyaan guru tidak hanya berfungsi untuk mengeksplorasi dan membuat siswa berpikir eksplisit namun juga berfungsi untuk membimbing dan membantu siswa selama kegiatan Inkuiri. Argumen (argument) dan penjelasan (explanation) membentuk 'tulang punggung' dari proses penyelidikan di kelas. Pertanyaan guru, baik yang diprakarsai oleh guru maupun sebagai tanggapan terhadap pertanyaan dan pengamatan siswa, memiliki potensi untuk menciptakan suasana yang kondusif bagi penalaran (reasoning) dan argumentasi (argumentation) yang berkelanjutan (Kawalkar \& Vijapurkar, 2013). Dialog Socrates merupakan teknik bertanya guru yang dapat diterapkan dalam pembelajaran inkuiri guna memfasilitasi argumentasi ilmiah siswa.

Berdasarkan uraian tersebut, maka dilakukan penelitian yang bertujuan untuk mengetahui ada atau tidaknya perbedaan kemampuan argumentasi ilmiah tertulis siswa melalui model pembelajaran Inkuiri Terbimbing dengan Inkuiri Terbimbing dipadu Dialog Socrates.

\section{METODE}

Penelitian ini menggunakan metode quasi experimental research. Penelitian dilaksanakan di SMA Negeri A Karanganyar pada semester genap tahun pelajaran 2018/2019. Subjek penelitian adalah siswa kelas XI IPA SMA Negeri A Karanganyar yang terdiri dari delapan kelas dengan jumlah 287 siswa. Teknik pengambilan sampel yang digunakan adalah cluster random sampling. Sampel dalam penelitian ini terdiri dari dua kelas yaitu kelas XI IPA 1 sebagai kelas eksperimen 1 dan kelas XI IPA 2 sebagai kelas eksperimen 2 yang seluruhnya berjumlah 72 siswa. Populasi sebelumnya telah melalui uji normalitas dan homogenitas dengan $\alpha=0,05$. Data yang digunakan dalam uji normalitas dan homogenitas adalah data hasil belajar ranah kognitif mata pelajaran Biologi dari nilai asli Penilaian Akhir Semester Ganjil. Hasilnya populasi bersifat normal dan homogen, sehingga sampel yang diambil dapat mewakili populasi.

Desain penelitian yang digunakan adalah post-test only with nonequivalent group design. Desain ini terdiri dari dua kelas, yaitu kelas eksperimen 1 dan kelas eksperimen 2. Kelas eksperimen 1 diberi perlakuan pembelajaran dengan model Inkuiri Terbimbing. Kelas eksperimen 2 diberi perlakuan pembelajaran dengan model Inkuiri Terbimbing dipadu Dialog Socrates. Kedua kelas kemudian diberikan post-test untuk mengukur kemampuan argumentasi ilmiah tertulis siswa. Hasil post-test kemudian dibandingkan untuk mengetahui ada atau tidaknya perbedaan kemampuan argumentasi ilmiah tertulis siswa melalui model Inkuiri Terbimbing dengan Inkuiri Terbimbing dipadu Dialog Socrates.

Teknik pengumpulan data yang digunakan dalam penelitian ini meliputi teknik tes dan teknik non tes. Teknik tes menggunakan tes tertulis berupa post-test untuk mengukur kemampuan argumentasi ilmiah tertulis siswa yang meliputi claim, evidence, dan reasoning. Post-test yang diberikan berupa soal uraian sebanyak 5 butir soal yang merujuk pada McNeill et al. (2006). Hasil tes kemudian dianalisis dengan menggunakan rubrik penilaian argumentasi oleh Wilson et al. (2010). Teknik non tes menggunakan lembar observasi untuk mengetahui kemampuan argumentasi ilmiah siswa selama proses pembelajaran yang dilatih melalui Dialog Socrates serta melihat keterlaksanaan model pembelajaran Inkuiri Terbimbing dan Inkuiri Terbimbing dipadu Dialog Socrates.

Instrumen tes yang digunakan untuk mengambil data telah melalui uji validitas dan reliabilitas. Validasi yang digunakan dalam penelitian ini meliputi validitas konstruk dan validitas isi. Uji validitas instrumen diukur melalui pendapat dari para ahli (judgment experts). Soal kemudian diujicobakan untuk selanjutnya dilakukan uji validitas dan reliabilitas. Uji validitas menggunakan teknik korelasi product moment dengan koefisien korelasi Pearson $(\alpha=0,05)$. Uji reliabilitas menggunakan rumus Alpha Cronbach $(\alpha=0,05)$. Hasil analisis menunjukkan bahwa instrumen soal dinyatakan valid dan reliabel.

Pengujian hipotesis yang digunakan adalah uji hipotesis komparatif dua sampel yang independen dengan uji t $(\alpha=0,05)$, untuk menguji signifikansi perbedaan nilai rata-rata argumentasi ilmiah tertulis antara kelas eksperimen 1 dan kelas eksperimen 2. Uji prasyarat yang harus dilakukan sebelum uji t meliputi uji normalitas dan uji homogenitas.

\section{HASIL DAN PEMBAHASAN}

Data utama kemampuan argumentasi ilmiah tertulis siswa diperoleh melalui tes tertulis berupa post-test. Soal post-test terdiri dari lima butir soal uraian yang mencakup seluruh materi pada KD 3.8. 
tentang Sistem Respirasi. Deskripsi data nilai argumentasi ilmiah tertulis siswa dari kelas eksperimen 1 dan kelas eksperimen 2 disajikan pada Tabel 1.

Tabel 1. Deskripsi Data Nilai Argumentasi Ilmiah Tertulis Kelas Eksperimen 1 dan Kelas Eksperimen 2

\begin{tabular}{lcc}
\hline \multicolumn{1}{c}{ Hasil Statistik } & Kelas Kontrol & Kelas Eksperimen \\
\hline $\mathrm{N}$ & 36 & 36 \\
Rata-rata & 65,99 & 74,44 \\
Standar Deviasi & 8,16 & 7,16 \\
Variansi & 66,56 & 51,22 \\
Median & 66,67 & 74,45 \\
Maksimum & 80,00 & 86,67 \\
Minimum & 51,11 & 62,22 \\
\hline
\end{tabular}

Tabel 1. menunjukkan bahwa nilai rata-rata argumentasi ilmiah tertulis pada kelas eksperimen 2 lebih tinggi $(74,44)$ dibandingkan kelas eksperimen $1(65,99)$. Standar deviasi dan variansi kelas eksperimen 2 lebih rendah $(7,16$ dan 51,22) dibandingkan kelas eksperimen $1(8,16$ dan 66,56), kondisi ini menunjukkan bahwa tingkat keragaman nilai pada kelas eksperimen 2 lebih kecil atau lebih homogen dibandingkan dengan kelas eksperimen 1. Median pada kelas eksperimen 2 lebih tinggi $(74,45)$ dibandingkan dengan kelas eksperimen 1 (66,57). Nilai maksimum dan minimum pada kelas eksperimen 2 juga menunjukkan hasil yang lebih tinggi $(86,67$ dan 62,22) dibandingkan dengan kelas eksperimen 1 (80,00 dan 51,11). Berdasarkan hasil tersebut maka secara umum dapat dikatakan bahwa kemampuan argumentasi ilmiah tertulis kelas eksperimen 2 yang menggunakan model pembelajaran Inkuiri Terbimbing dipadu Dialog Socrates lebih baik daripada kelas eksperimen 1 yang menggunakan model pembelajaran Inkuiri Terbimbing. Data perbandingan nilai rata-rata argumentasi ilmiah tertulis kelas eksperimen 1 dan kelas eksperimen 2 disajikan pada Gambar 1.

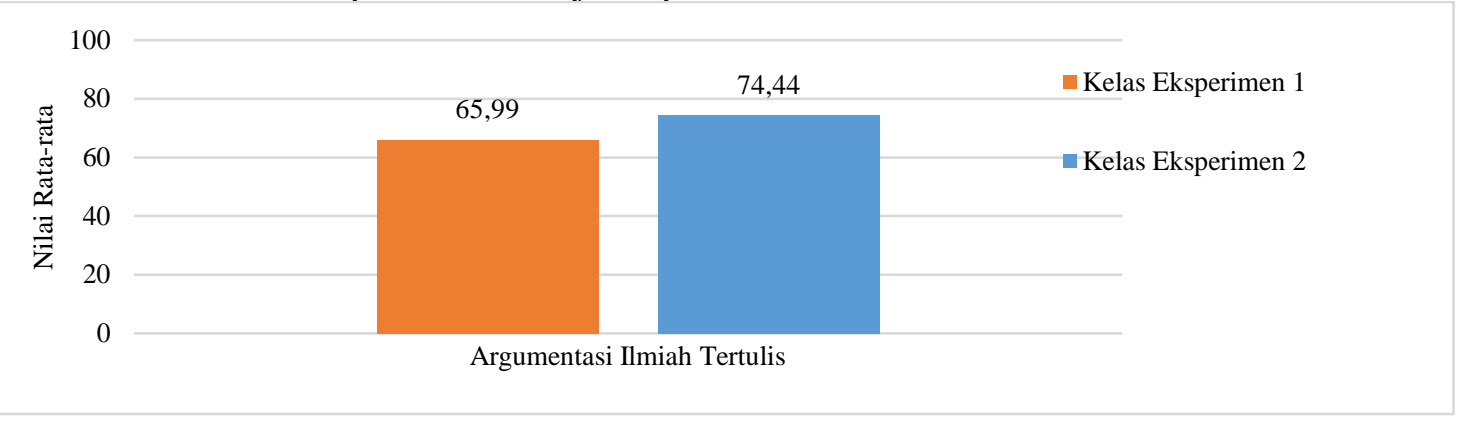

Gambar 1. Nilai Rata-rata Argumentasi Ilmiah Tertulis Kelas Eksperimen 1 dan Kelas Eksperimen 2

Berdasarkan Gambar 1. dapat diketahui bahwa nilai rata-rata argumentasi ilmiah tertulis kelas eksperimen 2 lebih tinggi $(74,44)$ dibandingkan dengan kelas eksperimen $1(65,99)$. Perbedaan nilai rata-rata antara kelas eksperimen 1 dan kelas eksperimen 2 menunjukkan bahwa kemampuan argumentasi ilmiah tertulis siswa lebih baik melalui model pembelajaran Inkuiri Terbimbing dipadu Dialog Socrates dibandingkan dengan model pembelajaran Inkuiri Terbimbing. Nilai rata-rata argumentasi ilmiah tertulis setiap aspek pada kelas eksperimen 1 dan kelas eksperimen 2 disajikan pada Gambar 2.

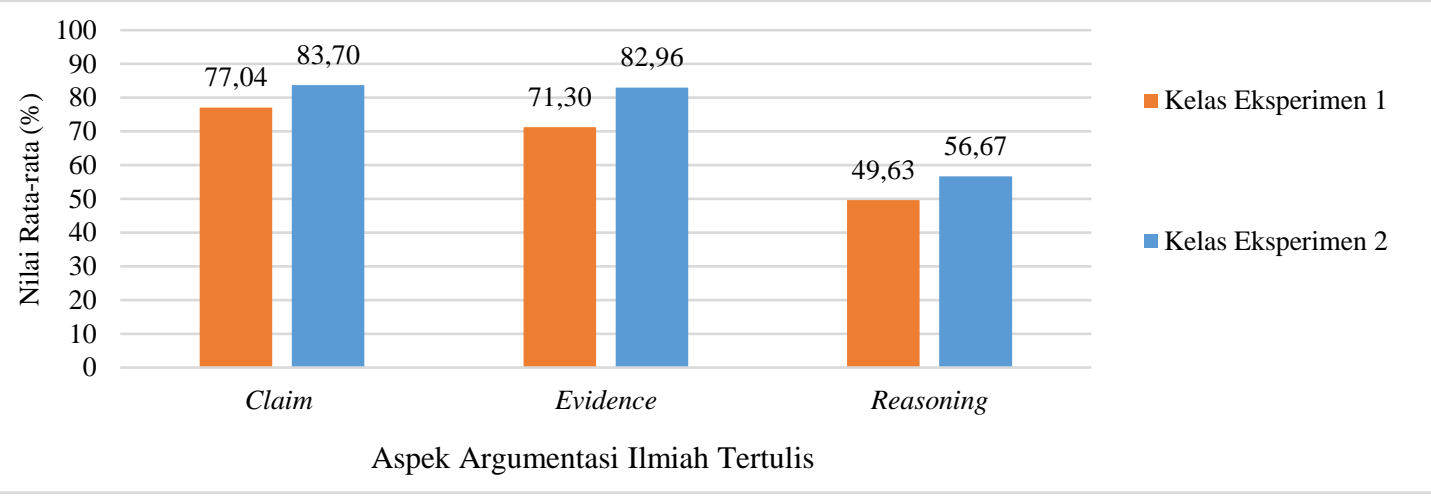

Gambar 2. Nilai Rata-rata Argumentasi Ilmiah Tertulis Kelas Eksperimen 1 dan Kelas Eksperimen 2 setiap Aspek 
Berdasarkan Gambar 2. dapat diketahui bahwa nilai rata-rata dari ketiga aspek argumentasi ilmiah tertulis kelas eksperimen 2 lebih tinggi dibandingkan kelas eksperimen 1. Aspek argumentasi ilmiah yang memiliki nilai rata-rata tertinggi pada kelas eksperimen 1 dan kelas eksperimen 2 adalah claim, sedangkan yang terendah adalah reasoning. Data pendukung diperoleh dari lembar observasi guna mengetahui kemampuan argumentasi ilmiah siswa selama proses pembelajaran yang dilatih melalui Dialog Socrates. Hasil observasi menunjukkan bahwa aspek argumentasi ilmiah berupa claim, evidence, dan reasoning telah muncul selama proses pembelajaran pada kelas eksperimen 2.

Pengujian hipotesis yang digunakan adalah uji t $(\alpha=0,05)$, untuk menguji signifikansi perbedaan nilai rata-rata argumentasi ilmiah tertulis antara kelas eksperimen 1 dan kelas eksperimen 2 . Uji prasyarat yang harus dilakukan sebelum uji t meliputi uji normalitas dan uji homogenitas. Perhitungan uji normalitas menggunakan Uji Kolmogorov-Smirnov $(\alpha=0,05)$. $\mathrm{H}_{0}$ dinyatakan bahwa data berdistri-busi normal. $\mathrm{H}_{1}$ dinyatakan bahwa data tidak berdistribusi normal. Jika nilai sig. dari uji normalitas lebih besar dari $\alpha$ (sig. > 0,05), maka $\mathrm{H}_{0}$ diterima sehingga dapat dikatakan bahwa data berdistribusi normal. Hasil uji normalitas nilai argumentasi ilmiah tertulis kelas eksperimen 1 dan kelas eksperimen 2 disajikan pada Tabel 2.

Tabel 2. Hasil Uji Normalitas Nilai Argumentasi Ilmiah Tertulis Kelas Eksperimen 1 dan Kelas Eksperimen 2

\begin{tabular}{cccc}
\hline Kelas & Sig. & Hasil & Keputusan \\
\hline Eksperimen 1 & 0,200 & sig. $>0,05$ & $\mathrm{H}_{0}$ diterima, Normal \\
Eksperimen 2 & 0,200 & sig. $>0,05$ & $\mathrm{H}_{0}$ diterima, Normal \\
\hline
\end{tabular}

Tabel 2. menunjukkan bahwa nilai sig. dari data nilai argumentasi ilmiah tertulis kelas eksperimen 1 dan kelas eksperimen 2 lebih besar daripada $\alpha$ (sig. $>0,05$ ), sehingga $\mathrm{H}_{0}$ diterima dan dapat dinyatakan bahwa data nilai argumentasi ilmiah tertulis kelas eksperimen 1 dan kelas eksperimen 2 yang diuji memiliki distribusi normal. Persyaratan lain yang digunakan untuk uji t adalah data harus homogen. Data homogen dapat diketahui dengan menggunakan uji homogenitas. Perhitungan uji homogenitas menggunakan Uji Levene's $(\alpha=0,05)$. $\mathrm{H}_{0}$ dinyatakan bahwa setiap kelas memiliki variansi yang sama (homogen). $\mathrm{H}_{1}$ dinyatakan bahwa setiap kelas tidak memiliki variansi yang sama. Jika nilai sig. dari uji homogenitas lebih besar dari $\alpha$ (sig. > 0,05), maka $\mathrm{H}_{0}$ diterima sehingga dapat dikatakan bahwa data homogen. Hasil uji homogenitas nilai argumentasi ilmiah tertulis kelas eksperimen 1 dan kelas eksperimen 2 disajikan pada Tabel 3.

Tabel 3. Hasil Uji Homogenitas Nilai Argumentasi Ilmiah Tertulis Kelas Eksperimen 1 dan Kelas Eksperimen 2

\begin{tabular}{cccc}
\hline Tes & Sig. & Hasil & Keputusan \\
\hline Nilai Argumentasi Ilmiah Tertulis & 0,456 & sig. $>0,05$ & $\mathrm{H}_{0}$ diterima, Homogen \\
\hline
\end{tabular}

Tabel 3. menunjukkan bahwa nilai sig. dari data nilai argumentasi ilmiah tertulis kelas eksperimen 1 dan kelas eksperimen 2 lebih besar daripada $\alpha$ (sig. $>0,05$ ), sehingga $\mathrm{H}_{0}$ diterima dan dapat dinyatakan bahwa data nilai argumentasi ilmiah tertulis kelas eksperimen 1 dan kelas eksperimen 2 yang diuji bersifat homogen.

Uji hipotesis yang digunakan adalah uji hipotesis komparatif dua sampel yang independen dengan uji t $(\alpha=0,05)$, untuk menguji signifikansi perbedaan nilai rata-rata argumentasi ilmiah tertulis. Data nilai argumentasi ilmiah tertulis pada penelitian dinyatakan normal dan homogen, sehingga prasyarat uji t telah terpenuhi. $\mathrm{H}_{0}$ dalam penelitian ini menyebutkan bahwa tidak ada perbedaan kemampuan argumentasi ilmiah tertulis siswa melalui model pembelajaran Inkuiri Terbimbing dengan Inkuiri Terbimbing dipadu Dialog Socrates, sedangkan $\mathrm{H}_{1}$ menyebutkan bahwa ada perbedaan kemampuan argumentasi ilmiah tertulis siswa melalui model pembelajaran Inkuiri Terbimbing dengan Inkuiri Terbimbing dipadu Dialog Socrates. Kriteria yang digunakan dalam pengambilan keputusan hipotesis adalah nilai $\mathrm{t}_{\text {hitung. }} \mathrm{H}_{0}$ ditolak jika nilai thitung lebih besar dari $\mathrm{t}_{\text {tabel }}\left(\mathrm{t}_{\text {hitung }}>\mathrm{t}_{\text {tabel }}\right)$. Hasil analisis perbandingan kemampuan argumentasi ilmiah tertulis siswa melalui model pembelajaran Inkuiri Terbimbing dengan Inkuiri Terbimbing dipadu Dialog Socrates melalui uji t disajikan pada Tabel 4.

Tabel 4. Hasil Analisis Perbandingan Kemampuan Argumentasi Ilmiah Tertulis Siswa melalui Model Inkuiri Terbimbing dengan Inkuiri Terbimbing dipadu Dialog Socrates

\begin{tabular}{ccccccc}
\hline Kelas & Mean & $\mathrm{t}_{\text {hitung }}$ & sig. & $\mathrm{t}_{(0,05 ; 70)}$ & Hasil & Keputusan Uji \\
\hline Eksperimen 1 & 65,99 & 4,675 & 0,000 & 1,99444 & $\mathrm{t}_{\text {hitung }}>\mathrm{t}_{\text {tabel }}$ & $\mathrm{H}_{0}$ ditolak \\
Eksperimen 2 & 74,44 & & & & & \\
\hline
\end{tabular}




\section{Jurnal Inovasi Pendidikan IPA, 6 (1), 2020 - 32}

Dewi Ekaputri Pitorini, Suciati Suciati, Joko Ariyanto

Tabel 4. menunjukkan bahwa nilai rata-rata argumentasi ilmiah tertulis siswa kelas eksperimen 1 adalah 65,99 dan nilai rata-rata argumentasi ilmiah tertulis siswa kelas eksperimen 2 adalah 74,44. Hasil uji $t$ menunjukkan bahwa $t_{\text {hitung }}$ lebih besar daripada $t_{\text {tabel }}(4,675>1,99444)$, sehingga $\mathrm{H}_{0}$ ditolak dan dapat dinyatakan bahwa ada perbedaan kemampuan argumentasi ilmiah tertulis siswa melalui model pembelajaran Inkuiri Terbimbing dengan Inkuiri Terbimbing dipadu Dialog Socrates. Nilai rata-rata kemampuan argumentasi ilmiah tertulis siswa kelas eksperimen 2 sebesar 74,44 lebih tinggi dibandingkan kelas eksperimen 1 yaitu sebesar 65,99 sehingga dapat diketahui bahwa kemampuan argumentasi ilmiah tertulis siswa lebih baik melalui model pembelajaran Inkuiri Terbimbing dipadu Dialog Socrates dibandingkan dengan model pembelajaran Inkuiri Terbimbing.

\section{Argumentasi Ilmiah Tertulis Aspek Claim}

Nilai rata-rata argumentasi ilmiah tertulis aspek claim kelas eksperimen 2 lebih tinggi yaitu 83,70 dibandingkan dengan kelas eksperimen 1 yaitu 77,04. Hasil kemampuan argumentasi ilmiah tertulis siswa didukung oleh data Dialog Socrates selama proses pembelajaran kelas eskperimen 2. Percakapan antara siswa dan guru dengan menggunakan Dialog Socrates menunjukkan bahwa aspek argumentasi ilmiah claim telah muncul selama proses pembelajaran kelas eksperimen 2. Venville dan Dawson (2010) menyatakan bahwa jika siswa dilatih untuk menyampaikan argumentasinya selama pembelajaran, maka mereka mampu menghasilkan argumentasi tertulis yang lebih rasional. Hasil penelitian tersebut berkaitan dengan karakteristik tahapan model pembelajaran Inkuiri Terbimbing dipadu Dialog Socrates, yaitu pada tahap conceptualization, conclusion, dan discussion.

Tahap conceptualization terdiri dari kegiatan menentukan rumusan masalah dan menyusun hipotesis (Pedaste, et al., 2015). Kegiatan merumuskan hipotesis pada tahap conceptualization melatih siswa mengajukan claim atau gagasan berdasarkan pengetahuan awal siswa. Guru membimbing siswa menentukan rumusan masalah dan hipotesis dengan menggunakan Dialog Socrates. Dialog Socrates yang diberikan guru mampu melatih siswa untuk menyampaikan argumentasi ilmiah aspek claim (Pangestika, et al., 2017). Tahap conceptualization dilakukan secara berkelompok, sehingga terjadi proses interaksi antar-siswa. Bimbingan yang diberikan oleh guru menyebabkan terjadinya interaksi antara guru dengan siswa. Interaksi sosial yang terjadi antar-siswa dan antara guru dengan siswa relevan dengan teori belajar sosiokultural Vygotsky. Teori belajar sosiokultural Vygotsky (Schunk, 2012) memandang bahwa interaksi dengan orang-orang dewasa dan teman-teman sebaya dalam ZPD dapat mendorong perkembangan kognitif. Interaksi yang terjadi pada tahap conceptualization mendorong siswa pada tingkat perkembangan aktual untuk dapat mencapai tingkat perkembangan potensial, sehingga dapat memfasilitasi siswa untuk mengembangkan kemampuan argumentasi ilmiah aspek claim. Hal ini didukung oleh pernyataan Nurinda et al., (2018a) bahwa komponen argumentasi claim diperoleh siswa setelah mereka dihadapkan dengan permasalahan atau konflik.

Tahap conclusion menuntut siswa untuk menyusun kesimpulan berdasarkan hasil penyelidikan (Pedaste et al., 2015). Kesimpulan disusun dalam bentuk argumentasi ilmiah, sehingga tahap conclusion dapat melatih argumentasi ilmiah aspek claim. Conclusion adalah tahap dimana siswa menghubungkan pengetahuan baru yang didapat dari penyelidikan dengan pengetahuan awal yang telah dimiliki. Hal tersebut relevan dengan teori belajar perkembangan kognitif Piaget mengenai asimilasi yang memandang asimilasi sebagai proses kognitif dimana seseorang mengintegrasikan konsep baru ke dalam skema atau pola yang sudah ada di dalam pikirannya (Suparno, 2001). Pada tahap conclusion, siswa tidak sekedar menghafal konsep-konsep, tetapi menghubungkan pengetahuan awal yang dimiliki dengan konsepkonsep yang telah diperoleh melalui kegiatan penyelidikan untuk menghasilkan pemahaman yang utuh sehingga konsep yang dipelajari akan dipahami secara baik dan tidak mudah dilupakan. Hal tersebut relevan dengan teori belajar bermakna Ausubel (Schunk, 2012) yang memandang bahwa belajar menjadi bermakna ketika materi baru memiliki hubungan sistematis dengan konsep-konsep yang relevan dalam struktur kognitif siswa. Pembelajaran yang bermakna dapat menghasilkan pemahaman konsep yang baik dalam diri siswa, sehingga kemampuan argumentasi ilmiah aspek claim juga dapat meningkat. Hal ini didukung oleh pernyataan National Research Council (1996) bahwa pembelajaran Inkuiri Terbimbing melatih siswa untuk menemukan serta meninjau kembali penjelasan saintifik dengan menggunakan logika dan bukti melalui kegiatan penyelidikan, sehingga dapat melatih argumentasi ilmiah aspek claim.

Tahap discussion menuntut siswa untuk mempresentasikan dan mengkomunikasikan temuan dan kesimpulan mereka kepada orang lain (Pedaste, et al., 2015), sehingga dapat melatih kemampuan argumentasi ilmiah aspek claim. Interaksi sosial yang terjadi pada tahap conclusion relevan dengan teori 
belajar sosiokultural Vygotsky (Schunk, 2012). Pada tahap discussion, siswa mempresentasikan hasil penyelidikan dan menerima umpan balik dari orang lain, hal tersebut relevan dengan teori belajar perkembangan kognitif Piaget. Teori perkembangan kognitif Piaget (Schunk, 2012) memandang ekuilibrasi sebagai mekanisme perkembangan kognitif yang utama. Ekuilibrasi terjadi melalui proses asimilasi dan akomodasi. Umpan balik yang diterima dapat memberikan pengetahuan baru bagi siswa. Asimilasi terjadi ketika pengetahuan baru memiliki kesesuaian dengan stuktur kognitif siswa. Akomodasi terjadi ketika siswa memperoleh pengetahuan baru yang sama sekali tidak cocok dengan struktur kognitif yang telah ada. Proses asimilasi dan akomodasi dapat mendorong perkembangan kognitif siswa. Jika pengetahuan yang dimiliki siswa berkembang maka kemampuan argumentasi ilmiah aspek claim juga dapat meningkat. Hal ini didukung oleh pernyataan National Research Council (1996) bahwa tahap discussion melatih siswa untuk mengkomunikasikan serta mempertahankan argumentasi ilmiahnya, sehingga dapat melatih argumentasi ilmiah aspek claim.

\section{Argumentasi Ilmiah Tertulis Aspek Evidence}

Nilai rata-rata argumentasi ilmiah tertulis aspek evidence kelas eksperimen 2 lebih tinggi yaitu 82,96 dibandingkan dengan kelas eksperimen 1 yaitu 71,30. Hasil kemampuan argumentasi ilmiah tertulis siswa didukung oleh data Dialog Socrates selama proses pembelajaran kelas eskperimen 2. Aspek argumentasi ilmiah evidence telah muncul selama proses pembelajaran pada kelas eksperimen 2. Hasil penelitian tersebut berkaitan dengan karakteristik tahapan model pembelajaran Inkuiri Terbimbing dipadu Dialog Socrates, yaitu pada tahap investigation, conclusion, dan discussion.

Tahap investigation terdiri dari menyusun rancangan penyelidikan, melakukan penyelidikan, dan melakukan analisis data (Pedaste et al., 2015). Penyelidikan yang dilakukan melatih siswa untuk mengumpulkan bukti (evidence) guna mendukung gagasan yang diajukan. Guru menggunakan Dialog Socrates untuk membimbing siswa merancang penyelidikan dan melakukan analisis data. Dialog Socrates yang diberikan guru mampu melatih siswa untuk menyampaikan argumentasi ilmiah aspek evidence (Pangestika, et al., 2017). Etemadzadeh, et al. (2013) menambahkan bahwa salah satu kategori pertanyaan dalam Dialog Socates adalah pertanyaan yang menyelidiki alasan dan bukti sebagai dasar argumen, sehingga penggunaan Dialog Socrates selama pembelajaran dapat melatih argumentasi ilmiah aspek evidence. Tahap investigation dilakukan secara berkelompok dengan bimbingan dari guru, sehingga terjadi proses interaksi sosial. Interaksi sosial yang terjadi relevan dengan teori belajar sosiokultural Vygotsky (Schunk, 2012). Tahap investigation menuntut siswa mengembangkan pengetahuan mereka sendiri melalui kegiatan penyelidikan dengan bimbingan dari guru. Hal tersebut relevan dengan teori belajar penemuan Bruner (Schunk, 2012) yang memandang bahwa cara terbaik untuk mempelajari konsep adalah dengan mengkontruksi sendiri konsep. Pemahaman konsep siswa menjadi lebih baik jika siswa menemukan sendiri konsepnya, pemahaman konsep yang baik dapat meningkatkan kemampuan argumentasi ilmiah aspek evidence. Hal ini didukung oleh pernyataan Nurinda et al., (2018a) bahwa komponen argumentasi evidence diperoleh siswa melalui kegiatan pengamatan atau penyelidikan.

Tahap conclusion menuntut siswa untuk menyusun kesimpulan berdasarkan hasil penyelidikan (Pedaste et al., 2015). Tahap conclusion dapat melatih argumentasi ilmiah aspek reasoning karena kesimpulan disusun dalam bentuk argumentasi ilmiah. Pada tahap conclusion, siswa menghubungkan pengetahuan baru yang didapat dari penyelidikan dengan pengetahuan awal yang telah dimiliki. Hal tersebut relevan dengan teori belajar perkembangan kognitif Piaget mengenai asimilasi (Suparno, 2001). Pada tahap conclusion, siswa tidak sekedar menghafal konsep-konsep, tetapi menghubungkan pengetahuan awal yang dimiliki dengan konsep-konsep yang telah diperoleh melalui kegiatan penyelidikan untuk menghasilkan pemahaman yang utuh sehingga konsep yang dipelajari akan dipahami secara baik dan tidak mudah dilupakan. Hal tersebut relevan dengan teori belajar bermakna Ausubel (Schunk, 2012). Pembelajaran yang bermakna dapat menghasilkan pemahaman konsep yang baik dalam diri siswa, sehingga kemampuan argumentasi ilmiah aspek evidence juga dapat meningkat. Hal ini didukung oleh pernyataan National Research Council (1996) bahwa pembelajaran Inkuiri Terbimbing melatih siswa untuk menemukan serta meninjau kembali penjelasan saintifik dengan menggunakan logika dan bukti melalui kegiatan penyelidikan, sehingga dapat melatih argumentasi ilmiah aspek claim.

Tahap discussion menuntut siswa untuk mempresentasikan dan mengkomunikasikan temuan dan kesimpulan mereka kepada orang lain (Pedaste, et al., 2015), sehingga dapat melatih kemampuan argumentasi ilmiah aspek evidence. Interaksi sosial yang terjadi pada tahap discussion relevan dengan teori belajar sosiokultural Vygotsky (Schunk, 2012). Pada tahap discussion, siswa mempresentasikan hasil 
penyelidikan dan menerima umpan balik dari orang lain, hal tersebut relevan dengan teori belajar perkembangan kognitif Piaget mengenai ekuilibrasi (Schunk, 2012). Ekuilibrasi dapat mendorong perkembangan kognitif siswa. Jika pengetahuan yang dimiliki siswa berkembang maka kemampuan argumentasi ilmiah aspek evidence juga dapat meningkat. Hal ini didukung oleh pernyataan National Research Council (1996) bahwa tahap discussion melatih siswa untuk mengkomunikasikan serta mempertahankan argumentasi ilmiahnya, sehingga dapat melatih argumentasi ilmiah aspek evidence.

\section{Argumentasi Ilmiah Tertulis Aspek Reasoning}

Nilai rata-rata argumentasi ilmiah tertulis aspek reasoning kelas eksperimen 2 lebih tinggi yaitu 65,67 dibandingkan dengan kelas eksperimen 1 yaitu 49,63. Hasil kemampuan argumentasi ilmiah tertulis siswa didukung oleh data Dialog Socrates selama proses pembelajaran kelas eskperimen 2. Percakapan antara siswa dan guru dengan menggunakan Dialog Socrates menunjukkan bahwa aspek argumentasi ilmiah reasoning telah muncul selama proses pembelajaran kelas eksperimen 2. Hasil penelitian tersebut berkaitan dengan karakteristik tahapan model pembelajaran Inkuiri Terbimbing dipadu Dialog Socrates, yaitu pada tahap investigation, conclusion, dan discussion.

Kegiatan analisis data pada proses penyelidikan melatih siswa untuk membangun pembenaran (reasoning) guna menguatkan claim yang diajukan. Guru menggunakan Dialog Socrates untuk membimbing siswa merancang penyelidikan dan melakukan analisis data. Dialog Socrates yang diberikan guru mampu melatih siswa untuk menyampaikan argumentasi ilmiah aspek reasoning (Pangestika, et al., 2017). Etemadzadeh, et al. (2013) menambahkan bahwa salah satu kategori pertanyaan dalam Dialog Socates adalah pertanyaan yang menyelidiki alasan dan bukti sebagai dasar argumen, sehingga penggunaan Dialog Socrates selama pembelajaran dapat melatih argumentasi ilmiah khususnya aspek reasoning. Tahap investigation dilakukan secara berkelompok dengan bimbingan dari guru, sehingga terjadi proses interaksi sosial. Interaksi sosial yang terjadi relevan dengan teori belajar sosiokultural Vygotsky (Schunk, 2012). Tahap investigation menuntut siswa mengembangkan pengetahuan mereka sendiri melalui kegiatan penyelidikan dengan bimbingan dari guru. Hal tersebut relevan dengan teori belajar penemuan Bruner (Schunk, 2012). Pemahaman konsep siswa menjadi lebih baik ketika siswa menemukan sendiri konsepnya, pemahaman konsep yang baik dapat meningkatkan kemampuan argumentasi ilmiah aspek reasoning. Hal ini didukung oleh pernyataan Nurinda et al., (2018a) bahwa komponen argumentasi reasoning dapat dilatihkan melalui kegiatan analisis hasil pengamatan atau penyelidikan dan kegiatan diskusi.

Tahap conclusion menuntut siswa untuk menyusun kesimpulan berdasarkan hasil penyelidikan (Pedaste et al., 2015). Pada tahap conclusion, siswa menyusun kesimpulan dalam bentuk argumentasi ilmiah, sehingga tahap conclusion dapat melatih argumentasi ilmiah aspek reasoning. Conclusion adalah tahap dimana siswa menghubungkan pengetahuan baru yang didapat dari penyelidikan dengan pengetahuan awal yang telah dimiliki. Hal tersebut relevan dengan teori belajar perkembangan kognitif Piaget mengenai asimilasi (Suparno, 2001). Pada tahap conclusion, siswa tidak sekedar menghafal konsepkonsep, tetapi menghubungkan pengetahuan awal yang dimiliki dengan konsep-konsep yang telah diperoleh melalui kegiatan penyelidikan untuk menghasilkan pemahaman yang utuh sehingga konsep yang dipelajari akan dipahami secara baik dan tidak mudah dilupakan. Hal tersebut relevan dengan teori belajar bermakna Ausubel (Schunk, 2012). Pembelajaran yang bermakna dapat menghasilkan pemahaman konsep yang baik dalam diri siswa, sehingga kemampuan argumentasi ilmiah aspek reasoning juga dapat meningkat. Hal ini didukung oleh pernyataan National Research Council (1996) bahwa pembelajaran Inkuiri Terbimbing melatih siswa untuk menemukan serta meninjau kembali penjelasan saintifik dengan menggunakan logika dan bukti melalui kegiatan penyelidikan, sehingga dapat melatih argumentasi ilmiah aspek reasoning.

Tahap discussion menuntut siswa untuk mempresentasikan dan mengkomunikasikan temuan dan kesimpulan mereka kepada orang lain (Pedaste, et al., 2015), sehingga dapat melatih kemampuan argumentasi ilmiah siswa aspek reasoning. Interaksi sosial yang terjadi pada tahap discussion relevan dengan teori belajar sosiokultural Vygotsky (Schunk, 2012). Pada tahap discussion, siswa mempresentasikan hasil penyelidikan dan menerima umpan balik dari orang lain, hal tersebut relevan dengan teori belajar perkembangan kognitif Piaget mengenai ekuilibrasi (Schunk, 2012). Ekuilibrasi mendorong perkembangan kognitif dalam diri siswa. Jika pengetahuan yang dimiliki siswa berkembang maka kemampuan argumentasi ilmiah aspek reasoning juga dapat meningkat. Hal ini didukung oleh pernyataan National 
Research Council (1996) bahwa tahap discussion melatih siswa untuk mengkomunikasikan serta mempertahankan argumentasi ilmiahnya, sehingga dapat melatih argumentasi ilmiah aspek reasoning.

Aspek argumentasi ilmiah claim memiliki nilai rata-rata tertinggi dibandingkan dengan aspek lainnya pada kelas eksperimen 1 dan kelas eksperimen 2. Hal ini sejalan dengan pernyataan Mcneill \& Martin (2010) bahwa claim adalah komponen yang paling sederhana dari suatu argumen dan seringkali merupakan bagian yang menurut siswa paling mudah. Aspek argumentasi ilmiah reasoning memiliki nilai rata-rata terendah dibandingkan dengan aspek lainnya pada kelas eksperimen 1 dan kelas eksperimen 2, hal tersebut sesuai dengan hasil penelitian McNeill, et al., (2006). Penelitian yang dilakukan oleh (McNeill et al., 2006) menunjukkan bahwa reasoning merupakan bagian yang paling sulit bagi siswa. Siswa mengalami kesulitan dalam menjelaskan mengapa data yang digunakan dianggap sebagai evidence untuk mendukung claim, serta kesulitan dalam menjelaskan hubungan antara claim dan evidence dengan memasukkan prinsip-prinsip ilmiah yang sesuai. Ketika siswa membangun argumentasi yang buruk, kesulitan siswa dapat berasal dari kurangnya pemahaman mereka mengenai konten atau kurangnya pemahanam mereka mengenai argumentasi. Salah satu alasan mengapa siswa mengalami kesulitan menyusun bagian reasoning adalah karena mereka belum memahami makna dari reasoning. Reasoning merupakan pernyataan yang menghubungkan evidence dan claim, siswa mungkin belum memahami apa yang dimaksud dengan 'menghubungkan'. Osborne, Erduran, dan Simon (2004) menambahkan bahwa kurangnya pengetahuan mengenai teori atau konsep yang relevan dapat menghambat siswa dalam menyusun reasoning. Dengan demikian Dialog Socrates berperan penting dalam penerapan model pembelajaran Inkuiri Terbimbing guna meningkatkan kemampuan argumentasi ilmiah khususnya aspek reasoning.

Hasil analisis data dengan menggunakan uji $t$ menunjukkan bahwa $t_{\text {hitung }}>\mathrm{t}_{\text {tabel }}$, sehingga $\mathrm{H}_{0}$ ditolak dan dapat dinyatakan bahwa ada perbedaan kemampuan argumentasi ilmiah tertulis siswa melalui model pembelajaran Inkuiri Terbimbing dengan Inkuiri Terbimbing dipadu Dialog Socrates. Nilai rata-rata kemampuan argumentasi ilmiah tertulis siswa kelas eksperimen 2 sebesar 74,44 lebih tinggi disbandingkan kelas eksperimen 1 yaitu sebesar 65,99 sehingga dapat diketahui bahwa kemampuan argumentasi ilmiah tertulis siswa lebih baik melalui model pembelajaran Inkuiri Terbimbing dipadu Dialog Socrates dibandingkan dengan model pembelajaran Inkuiri Terbimbing. Hal tersebut berkaitan dengan karakteristik tahapan model pembelajaran Inkuiri Terbimbing dipadu Dialog Socrates. Tahap conceptualization melatih argumentasi ilmiah aspek claim. Tahap investigation melatih argumentasi ilmiah aspek evidence dan reasoning. Tahap conclusion melatih argumentasi ilmiah aspek claim, evidence, dan reasoning. Tahap discussion melatih argumentasi ilmiah aspek claim, evidence, dan reasoning. Penggunaan Dialog Socrates selama pembelajaran Inkuiri Terbimbing sangat membantu dalam meningkatkan kemampuan argumentasi ilmiah. Dengan demikian guru disarankan untuk melatih kemampuan argumentasi ilmiah siswa dengan menggunakan pertanyaan-pertanyaan yang sifatnya membimbing.

Berdasarkan hasil pembahasan terlihat ada ada perbedaan kemampuan argumentasi ilmiah tertulis siswa melalui model pembelajaran Inkuiri Terbimbing dengan Inkuiri Terbimbing dipadu Dialog Socrates. Kemampuan argumentasi ilmiah tertulis siswa lebih baik melalui model pembelajaran Inkuiri Terbimbing dipadu Dialog Socrates dibandingkan dengan model pembelajaran Inkuiri Terbimbing.

\section{SIMPULAN}

Hasil penelitian menunjukkan bahwa nilai rata-rata argumentasi ilmiah tertulis kelas eksperimen lebih tinggi yaitu 74,44 dibandingkan dengan kelas kontrol yaitu 65,99. Hasil uji t menunjukkan bahwa $\mathrm{t}_{\text {hitung }}>\mathrm{t}_{\text {tabel }}(4,675>1,99444)$, artinya terdapat perbedaan kemampuan argumentasi ilmiah tertulis siswa yang signifikan antara kelas eksperimen dan kelas kontrol. Berdasarkan hasil penelitian dapat disimpulkan bahwa ada perbedaan kemampuan argumentasi ilmiah tertulis siswa melalui model pembelajaran Inkuiri Terbimbing dengan Inkuiri Terbimbing dipadu Dialog Socrates.

\section{DAFTAR PUSTAKA}

Acar, O., \& Patton, B. R. (2012). Argumentation and formal reasoning skillsin an argumentation-based guided inquiry course. Procedia - Social and Behavioral Sciences, 46, 4756-4760. https://doi.org/10.1016/j.sbspro.2012.06.331

Aisyah, I., \& Wasis, W. (2015). Penerapan model pembelajaran inkuiri untuk melatihkan kemampuan argumentasi ilmiah siswa pada materi kalor di SMAN 1 Pacet. Inovasi Pendidikan Fisika, 4(2), 


\section{Jurnal Inovasi Pendidikan IPA, 6 (1), 2020 - 36}

Dewi Ekaputri Pitorini, Suciati Suciati, Joko Ariyanto

83-87.

fisika/article/view/12304

https://jurnalmahasiswa.unesa.ac.id/index.php/inovasi-pendidikan-

Amielia, S. D., Suciati, S., \& Maridi, M. (2017). Profil keterampilan argumentasi siswa SMA Negeri 5 Surakarta. Seminar Nasional Pendidikan Sains, 163-168.

Aslan, S. (2014). Analysis of students' written scientific argument generate and evaluation skills. Journal of Theory and Practice in Education, 10(1), 41-74. http://acikerisim.lib.comu.edu.tr:8080/xmlui/handle/COMU/1126

Bass, J. E., Contant, T. L., \& Carin, A. A. (2008). Teaching science as inquiry (11th ed.). Pearson.

Bathgate, M., Crowell, A., Schunn, C., Cannady, M., \& Dorph, R. (2015). The learning benefits of being willing and able to engage in scientific argumentation. International Journal of Science Education, 37(10), 1590-1612. https://doi.org/10.1080/09500693.2015.1045958

Deane, P., \& Song, Y. (2014). A case study in principled assessment design: Designing assessment to measure and support development of argumentative reading and writing skill. Psicologia Educativa, 12(2), 85-99. https://doi.org/10.1016/j.pse.2014.10.001

Duschl, R. A., \& Osborne, J. (2002). Supporting and promoting argumentation discourse in science education. Studies in Science Education, 38(1), 39-72. https://doi.org/10.1080/03057260208560187

Etemadzadeh, A., Seifi, S., \& Far, H. R. (2013). The role of questioning technique in developing thinking skills: The ongoing effect on writing skill. Procedia - Social and Behavioral Sciences, 70, 1024-1031. https://doi.org/10.1016/j.sbspro.2013.01.154

Faize, F. A., Husain, W., \& Nisar, F. (2017). A critical review of scientific argumentation in science education. Eurasia Journal of Mathematics, Science and Technology Education, 14(1), 475-483. https://doi.org/10.12973/ejmste/80353

Gumilar, S., \& Budiman, D. M. (2018). Meningkatkan argumentation skill dan kemampuan kognitif calon guru IPA SD melalui socratic method. Gravity, 4(1), 23-32. https://doi.org/10.30870/gravity.v4i1.3115

Kawalkar, A., \& Vijapurkar, J. (2013). Scaffolding science talk: The role of teachers' questions in the inquiry classroom. International Journal of Science Education, 35(12), 2004-2027. https://doi.org/10.1080/09500693.2011.604684

Koellner-Clark, K., Stallings, L. L., \& Hoover, S. A. (2002). Socratic seminars for mathematics. Mathematics $\quad$ Teacher, 682-687. https://www.sjsd.k12.mo.us/cms/lib/MO01001773/Centricity/Domain/75/socratic-seminararticle.pdf

Kuhlthau, C. C., Caspari, A. K., \& Maniotes, L. K. (2007). Guided inquiry: Learning in the 21st century. ABC-CLIO.

Kulsum, \& Nugraha. (2014). Penerapan model pembelajaran cooperative problem solving untuk meningkatkan kemampuan pemahaman konsep dan komunikasi ilmiah siswa pada mata pelajaran fisika. Unnes Physics Education Journal, 18(2), 25-32. https://doi.org/10.15294/upej.v3i2.3600

Kurniasari, I. S., \& Setyarsih, W. (2017). Penerapan model pembelajaran argument driven inquiry (ADI) untuk melatihkan kemampuan argumentasi ilmiah siswa pada materi usaha dan energi. Inovasi Pendidikan Fisika, 06(03), 171-174. https://jurnalmahasiswa.unesa.ac.id/index.php/inovasipendidikan-fisika/article/view/20276

McNeill, K. L., Lizotte, David, J., Krajcik, J., \& Marx, R. W. (2006). Supporting students' construction of scientific explanations by fading scaffolds in instructional materials. The Journal of the Learning Sciences, 15(2), 153-191. https://doi.org/10.1207/s15327809j1s1502

Mcneill, K. L., \& Martin, D. (2010). Strengthening science writing and inquiry: Helping students develop claims with evidence and reasoning. National Science Teachers Association, 2-9.

National Research Council. (1996). National science education standards. National Research Council.

Nurinda, S., Sajidan, \& Prayitno, B. A. (2018a). Effectiveness of problem-based learning module as an 
instructional tool in improving scientific argumentation skill. Biosaintifika, 10(2), 334-340. https://doi.org/10.15294/biosaintifika.v10i2.12600

Nurinda, S., Sajidan, S., \& Prayitno, B. A. (2018b). Enhancing High School Students's Rebuttals as An Important Aspect of Scientific Argumentation Skill Through Problem Based Learning. Proceedings of the 1st Annual International Conference on Mathematics, Science, and Education (ICoMSE 2017), 218, 201-204. https://doi.org/10.2991/icomse-17.2018.35

Organisation for Economic Co-Operation and Development. (2016). PISA 2015 results (Volume I): Excellence and equity in education: Vol. I. OECD. https://doi.org/10.1787/9789264266490-en

Osborne, J. (2010). Arguing to learn in science: The role of collaborative, critical discourse. Science, 328(5977), 463-466. https://doi.org/10.1126/science.1183944

Osborne, J., Erduran, S., \& Simon, S. (2004). Enhancing the quality of argumentation in school science. Journal of Research in Science Teaching, 41(10), 994-1020. https://doi.org/10.1002/tea.20035

Pangestika, I. W., Ramli, M., \& Nurmiyati. (2017). The changing of oral argumentation process of grade XI students through socratic dialogue. International Journal of Science and Applied Science, 2(1), 198-208. https://doi.org/10.20961/ijsascs.v2i1.16710

Pangestika, I. W., Ramli, M., Nurmiyati, N., \& Sapartiwi, S. (2017). Hasil belajar biologi siswa kelas XI MIPA melalui penerapan dialog socrates. Proceeding Biology Education Conference, 14(1), 305-310. https://jurnal.uns.ac.id/prosbi/article/view/17872

Pedaste, M., Mäeots, M., Siiman, L. A., de Jong, T., van Riesen, S. A. N., Kamp, E. T., Manoli, C. C., Zacharia, Z. C., \& Tsourlidaki, E. (2015). Phases of inquiry-based learning: Definitions and the inquiry cycle. Educational Research Review, 14, 47-61. https://doi.org/10.1016/j.edurev.2015.02.003

Schunk, D. H. (2012). Learning theories: An educational perspective. Pearson.

Simbolon, D. H. (2015). Pengaruh model pembelajaran inkuiri terbimbing berbasis eksperimen riil dan laboratorium virtual terhadap hasil belajar fisika siswa. Jurnal Pendidikan Dan Kebudayaan, 21(3), 299-316. https://doi.org/10.24832/jpnk.v21i3.192

Suparno, P. (2001). Teori perkembangan kognitif jean piaget. Kanisius.

Thoron, A., \& Myers, B. (2012). Effects of inquiry-based agriscience instruction on student scientific reasoning. Journal of Agricultural Education, 53(4), 156-170. https://doi.org/10.5032/jae.2012.04156

Trilling, B., \& Fadel, C. (2009). 21 st century skills: Learning for life in our times. Jossey-Bass.

Venville, G. J., \& Dawson, V. M. (2010). The impact of a classroom intervention on grade 10 students' argumentation skills, informal reasoning, and conceptual understanding of science. Journal of Research in Science Teaching, 47(8), 952-977. https://doi.org/10.1002/tea.20358

Vyskočilová, J., \& Praško, J. (2012). Socratic dialogue and guided discovery in cognitive behavioral supervision. Activitas Nervosa Superior Rediviva, 54(1), 35-45. http://www.rediviva.sav.sk/54i1/35.pdf

Wenning, C. J. (2005). Levels of inquiry: Hierarchies of pedagogical practices and inquiry processes. $\begin{array}{llll}\text { Journal of Physics Teacher 2(3), 3-12. } & \text { Education, }\end{array}$ http://www.phy.ilstu.edu/pte/publications/levels_of_inquiry.pdf

Whiteley, T. R. (2006). Using the socratic method and Bloom's taxonomy of the cognitive domain to enhance online discussion, critical thinking, and student learning. Developments in Business Simulation and Experiential Learning, 33, 65-70. https://absel-ojsttu.tdl.org/absel/index.php/absel/article/view/499

Wibawa, R. A. P., Prayitno, B. A., \& Marjono, M. (2017). Penerapan problem based learning pada materi pencemaran lingkungan untuk meningkatkan kemampuan argumentasi ilmiah tertulis siswa kelas X MIPA. Proceeding Biology Education Conference: Biology, Science, Enviromental, and Learning, 14(1), 361. https://jurnal.uns.ac.id/prosbi/article/view/18808

Wilson, C. D., Taylor, J. A., Kowalski, S. M., \& Carlson, J. (2010). The relative effects and equity of 
Jurnal Inovasi Pendidikan IPA, 6 (1), 2020 - 38

Dewi Ekaputri Pitorini, Suciati Suciati, Joko Ariyanto

inquiry-based and commonplace science teaching on students' knowledge, reasoning, and argumentation. Journal of Research in Science Teaching, 47(3), 276-301. https://doi.org/10.1002/tea.20329

Yengin, I., \& Karahoca, A. (2012). "What is socratic method?" the analysis of socratic method through "self determination theory" and "unified learning model." Information Technology \& Computer Science, 2, 357-365. http://archives.un-pub.eu/index.php/P-ITCS/article/viewArticle/670 